\title{
Microhabitat preferences of the freshwater prawn Macrobrachium jelskii (Decapoda: Palaemonidae)
}

\author{
Jersei N. Silva', Guilherme de Oliveira² \& Sérgio S. da Rocha' ${ }^{1}$
}

\begin{abstract}
1.Laboratório de Bioecologia de Crustáceos, Centro de Ciências Agrárias, Ambientais e Biológicas, Universidade Federal do Recôncavo da Bahia, Rua Rui Barbosa, 710, Centro, 44380-000 Cruz das Almas, BA, Brazil. (jerseinascimento@hotmail.com; ssrocha@ufrb.edu.br)

2. Laboratório de Biogeografia da Conservação, Centro de Ciências Agrárias, Ambientais e Biológicas, Universidade Federal do Recôncavo da Bahia
\end{abstract} Rua Rui Barbosa, 710, Centro, 44380-000 Cruz das Almas, BA, Brazil. (guilhermeoliveira@ufrb.edu.br)

Received 4 July 2018

Accepted 31 May 2019

Published 15 July 2019

DOI 10.1590/1678-4766e2019027

\begin{abstract}
We analyzed the microhabitat preferences of Macrobrachium jelskii (Miers, 1877) males and females inhabiting an urban water reservoir in Cruz das Almas, Bahia, Brazil. Prawns were collected monthly, from March 2015 to February 2016, in three microhabitats, using a sieve. Each microhabitat was dominated by one macrophyte species: Eleocharis sp. (M1), Cabomba sp. (M2), and Nymphaea sp. (M3). The prawns were measured (carapace length), and categorized as juvenile males, adult males, juvenile females, non-ovigerous adult females and ovigerous adult females. An analysis of variance (ANOVA) was used to compare the number and size of individuals. The sex ratio and frequency of ovigerous females in the three microhabitats were also calculated. The sex ratio was biased towards females in M1 and did not deviate from 1:1 in M2 and M3. When prawns were separated into five categories we observed that non-ovigerous adult females were more abundant in M1, while adult males were the most abundant demographic category in M2 and M3. Juveniles of both sexes and ovigerous females showed no microhabitat preference, although M1 and M2 appeared to be more suitable for the latter. Adult females were the largest individuals in all microhabitats. Food availability, lower depth and lower predation pressure in M1 are the main factors that make M1 more suitable for $M$. jelskii, particularly non-ovigerous adult females and larger adult males. Intraspecific competition for shelter in M1 might also occur and adult females win this competition due to their larger body size. Therefore, adult males are found in higher abundance in M2 and M3 and the juvenile of both sexes spread evenly across all microhabitats. Our results help to understand the ecological role and the niche used by M. jelskii. Future studies on the habitat choice and predation under laboratory conditions should help to understand the behavior of this species.
\end{abstract}

KEYWORDS. Macrophyte, population structure, reproduction, spatial distribution.

RESUMO. Preferência de micro-habitat pelo camarão de água doce Macrobrachium jelskii (Decapoda: Palaemonidae). Nós analisamos as preferências de micro-habitat de machos e fêmeas de Macrobrachium jelskii (Miers, 1877) em um açude urbano em Cruz das Almas, Bahia, Brasil. As amostras foram coletadas mensalmente, de março de 2015 a fevereiro de 2016, com o auxílio de uma peneira em três diferentes micro-habitats. Cada microhabitat teve predomínio de uma espécie de macrófita: Eleocharis sp. (M1), Cabomba sp. (M2) e Nymphaea sp. (M3). Os camarões foram categorizados como machos (jovens e adultos) e fêmeas jovens, adultas não ovígeras e ovígeras e tiveram seu comprimento de carapaça medido. A ANOVA foi usada para comparar as diferenças entre o número e o tamanho dos indivíduos entre os micro-habitats. A razão sexual e a frequência de fêmeas ovígeras em cada micro-habitat também foram calculadas. A razão sexual foi desviada para as fêmeas em M1, mas em M2 e M3 não houve diferença do padrão 1: 1. Quando os camarões foram separados nas cinco categorias, observamos que as fêmeas adultas não ovígeras foram mais abundantes em M1, enquanto os machos adultos foram a categoria demográfica mais abundante em M2 e M3. Indivíduos jovens não mostraram preferência por nenhum dos microhabitats. M1 e M2 se mostraram adequados para fêmeas ovígeras, devido à maior frequência destas nestes dois micro-habitats se comparado à M3. As fêmeas adultas foram os maiores indivíduos em todos os micro-habitats. A disponibilidade de alimento, a menor profundidade e a menor pressão de predação em M1 são os principais fatores que tornam este micro-habitat mais adequado para M. jelskii, particularmente para fêmeas adultas não ovígeras e machos adultos e fêmeas jovens de maiores tamanhos. Além disso, consideramos também a competição intraespecífica por abrigo em M1, a qual as fêmeas adultas vencem devido ao seu maior tamanho corporal. Como consequência, os machos adultos são encontrados em maior abundância em M2 e M3 e os juvenis de ambos os sexos se espalham uniformemente em todos os micro-habitats. Nossos resultados ajudam a entender o papel ecológico e a utilização de nicho por M. jelskii. Futuros estudos sobre a escolha do habitat e relação presa-predador em condições de laboratório poderão ajudar a entender melhor o comportamento dessa espécie.

PALAVRAS-CHAVE. Macrófita, estrutura de população, reprodução, distribuição espacial.

Animals often search for habitats that can fulfill their biological needs (e.g. feeding, reproduction, and avoidance of predators) (MüLleR et al., 1999; RochA, 2010). In freshwater environments there is a stratification of the fauna directly related to the environmental conditions and shelter availability (ThOMAZI et al., 2008; GiULIATTI \& CARVALHO,
2009). This stratification occurs due to predation pressure and food resources that are exploited by different species throughout their life phases (Merrit \& Cummins, 1996; MARQues et al., 1999; ThOMAZI et al., 2008; FerREIRA et al., 2010). In this context, the occurrence, abundance, and type of macrophytes forming a microhabitat strongly influence 
freshwater communities, as they provide nutritional resources, shelter, and breeding places for phytophilic invertebrates (COOK \& Streams, 1984; TAKeda et al., 2003; LAMmers $e t$ al., 2009a,b; THOMAZ \& CunHA, 2010).

A differential microhabitat occupation related to resources and shelter availability was already evidenced in previous studies on freshwater prawns of the families Atiidae (DARnell, 1956; Lima \& Oshiro, 2002) and Palemonidae (WALKer \& Ferreira, 1985; Williner \& Collins, 2002; Montoya, 2003; Lammers et al., 2009a; Rocha, 2010; Bentes et al., 2011; Paschoal et al., 2013; Teixeira \& Couto, 2012). Among the Palemonidae representatives, Macrobrachium jelskii (Miers, 1877) is often found associated with macrophyte banks of lotic and lentic water bodies (Williner \& Collins, 2002; Montoya, 2003).

Macrobrachium jelskii is popularly known in Brazil as "camarão-sossego" (PAIvA \& BARReto, 1960) and it is among the 19 species of Macrobrachium Spence Bate, 1868 occurring in the Brazilian territory (De Grave \& Fransen, 2011; Maciel et al., 2011; Pileggi \& Mantelatto, 2012; De Grave \& Ashelby, 2013; Santos et al., 2013; Vera-Silva et al., 2016). The type-locality of M. jelskii is Saint-Georges, in French Guiana, but it is widely distributed throughout South America (PILEGGI et al., 2013). In Brazil, it has been recorded in the states of Amapá, Pará, Amazonas, Maranhão, Ceará, Rio Grande do Norte, Paraíba, Pernambuco, Alagoas, Sergipe, Bahia, Minas Gerais, Rio de Janeiro, Espírito Santo, Mato Grosso, São Paulo, and Santa Catarina (Melo, 2003; PilegGr et al., 2013). However, the occurrence of $M$. jelskii in hydrographic basins of Northeast and Southeast Brazil might be considered the result of anthropogenic actions (Magalhães et al., 2005; Vera-Silva et al., 2016, 2017).

As part of the food chain of limnic environments, M. jelskii has a high ecological importance in these environments, feeding upon insect larvae, diatom and other algae, and sediment grains (Melo, 2003; CiRILO et al., 2011). In addition, like all caridean prawns, it is a prey of fishes and other animals (BAUER, 2004; MAGALHÃEs et al., 2014). From the economic point of view, M. jelskii is important in some regions of Brazil (e.g. state of Sergipe), and exploited as fishing bait, aquarium ornamentation, and food resource by the riverine population (CIRILO et al., 2011; Vera-SiLVA et al., 2016).

Macrobrachium jelskii has a "partially abbreviated" development (sensu JALIHAL et al., 1993). Its females carry few, large eggs (ANGER, 2013), and the benthic larvae go through three developmental stages independent from brackish or salty water (GAMBA, 1984; MAGALHÃES, 2000). Therefore, the species is frequent in interior waters; lotic and lentic environments; dark and clear waters; muddy, rocky, and sandy substrates; and amongst roots of aquatic plants and grasses (Magalhães, 2000; Melo, 2003; Montoya, 2003; CIRILO et al., 2011).

Here we investigated a population of M. jelskii in Cruz das Almas municipality, State of Bahia, Brazil. Since M. jelskii is a phytophilic species, we investigated its microhabitat preference, comparing its abundance in three types of macrophytes and considering its population structure in each microhabitat. We compared the total abundance and size (carapace length), between males and females of two classes of sexual maturity (juvenile and adult). Using information from the literature, we discuss the possible ecological factors influencing the population structure and microhabitat preference. Finally, we believe that our results give an important contribution to the knowledge of the ecology of this species, which is widely distributed throughout South American water bodies.

\section{MATERIAL AND METHODS}

Study area. Specimens of Macrobrachium jelskii were collected monthly from March 2015 to February 2016, at Doutor Braz Water Reservoir (12 40’06.6”'S; 3907'11.2”W) which is located within the city limits of Cruz das Almas (Fig. 1). The reservoir is a typical lentic environment, with surrounding riparian vegetation composed mainly of ground cover and herbaceous species. Different types of aquatic macrophytes are present, wholly or partially submerged, been Eleocharis sp., Cabomba sp., and Nymphaea sp. the most abundant.

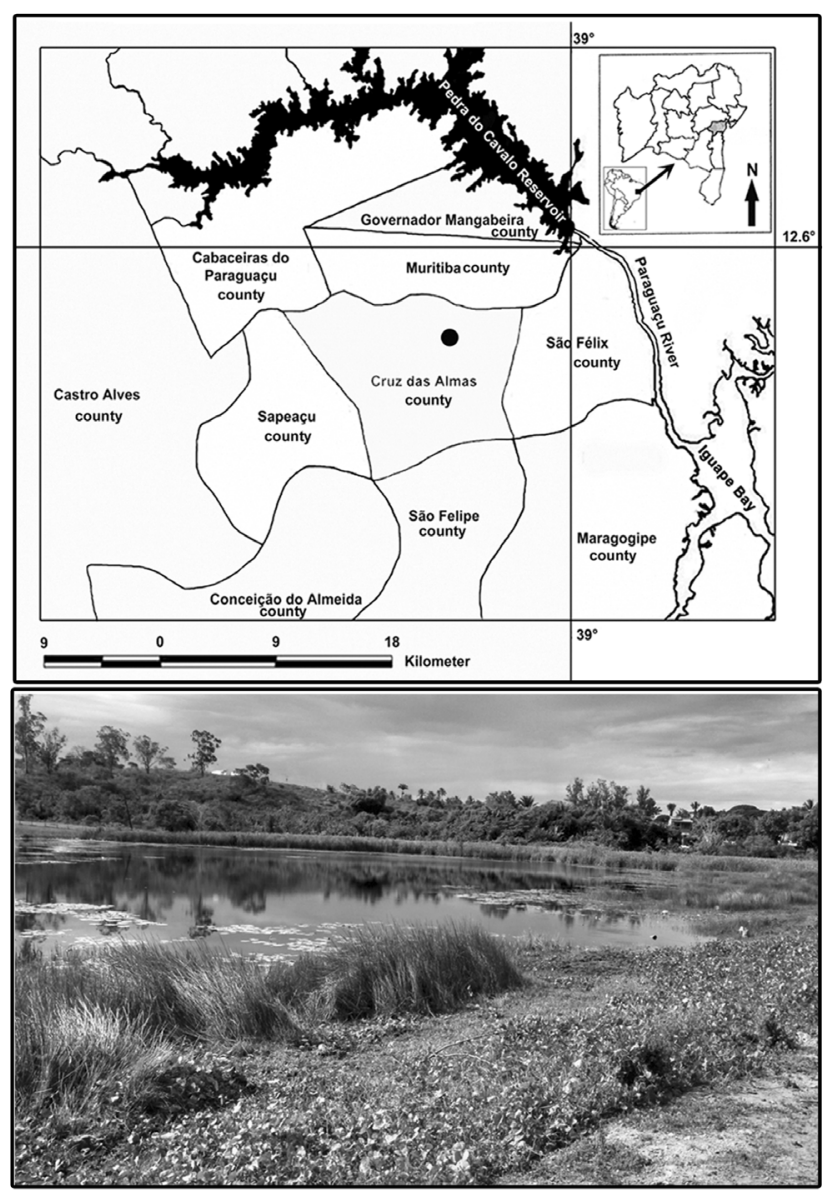

Fig. 1. Map of Recôncavo da Bahia, Brazil. Black area, Pedra do Cavalo Reservoir; black circle, urban area of Cruz das Almas, Bahia (map above). Sampling site, Doutor Braz Water Reservoir (1240’06.6”'S, 3907'11.2”'W) (photograph below). 
Sampling protocol. The sampling sites were visually chosen according to the type and abundance of aquatic macrophytes to ensure there was no overlap between the macrophyte species. Thus, three microhabitats were selected, each one dominated by one of the most abundant macrophytes of the water reservoir: Eleocharis sp. (M1), Cabomba sp. (M2) or Nymphaea sp. (M3). It is important to note that during the pilot study, no prawns were found in sites lacking vegetation.

The three microhabitats differed both in density (see DiBBLE et al., 1996 for review) and distribution, which were estimated visually. M1 was a dense, marginal and emergent vegetation, found at depths shallower than $40 \mathrm{~cm}$. M2 was a dense and always submerged vegetation, found at depths between 50 and $100 \mathrm{~cm}$. M3 formed a less dense vegetation, with floating leaves connected to the submerged stem by long petioles, and it was dominant at higher depths (deeper than $100 \mathrm{~cm}$ ).

In addition, numerous studies estimating spatial complexity (created by stems and leaves) and plant architecture of aquatic macrophyte species have shown that Cabomba sp. has greater spatial complexity than Eleocharis sp. and Nymphaea sp., the latter being the one with the lowest complexity (TANigUCHI et al., 2003; WARFE \& BARMUTA, 2004; McAbendroth et al., 2005; Dibble \& Thomaz, 2006, 2009; WARFE et al., 2008; CASARTELli \& FerRaGUT, 2018). Thus, we could classify the microhabitats evaluated in the present study in an increasing order of complexity, as follows: M3 (the simplest); M1 (intermediate complexity); and M2 (the most complex).

Specimens of M. jelskii were captured by sweeping a sieve (diameter $50.0 \mathrm{~cm}, 0.5 \mathrm{~mm}$ mesh) through the vegetation of each microhabitat. The sampling effort consisted of the activity of four people during 10 minutes in each microhabitat.

In the laboratory, the prawns were identified according to Melo (2003). The sex was determined based on the presence (males) or absence (females) of the appendix masculina on the second pair of pleopods. Males were categorized as juveniles and adults based on the developmental stage of the appendix masculina observed under the microscope. Only those having a fully developed appendix masculina were considered adults, since studies indicated that this structure is important during the spermatophore transference and is only functional when fully developed (BAUER, 1976, 2004; BERG $\&$ SANDIFER, 1984). Females were categorized as juveniles or adults based on the average size of sexual maturity $(\mathrm{CL}=$ $6.67 \mathrm{~mm}$ ) estimated by Rocha \& Barbosa (2017). Therefore, prawns were separated into five demographic groups: juvenile males, adult males, juvenile females, non-ovigerous adult females and ovigerous adult females. All individuals had their carapace length $(\mathrm{CL}=$ from the postorbital margin to the posterior margin of the carapace) measured with a digital caliper ( $0.01 \mathrm{~mm}$ precision). Afterwards, they were fixed in $70 \%$ ethanol and kept in labeled flasks. Voucher specimens were deposited at the Museum of Zoology, Universidade Federal do Sul da Bahia, Brazil (accession number M20180358UFSB).

Statistical analyses. The Qui-square test was used to verify the differences between the overall sex ratio. A two-way
ANOVA was used to check differences among the abundance of each demographic group and microhabitats. We used the abundance as a response variable, and demographic group, and microhabitat (M1, M2, and M3) as categorical variables. We calculated the ANOVA two-way in two different ways; first, the analysis was performed separating the demographic group into male and female. Second, the analysis was done subdividing males and females into five demographic groups. Significant differences would indicate microhabitat preferences. This same analysis was done using the CL as response variable to check for differences in body size among demographic groups and microhabitats. All statistical analyses were performed based on SOKAL \& ROHLF (1995) and ZAR (1996) using Statistica 7.0 $\left(\right.$ Statsoft $\left.^{\circledR}\right)$ and Microsoft Office EXCEL $^{\circledR} 2003$ or later, with level of significance of $P<0.05$.

Finally, we tested the residuals of the ANOVAs for the assumptions of normality using a Kolmogorov-Smirnov test (SOKAL \& ROHLF, 1995). Homoscedasticity assumption was also tested using the statistics of Hartley (maximum value of F), Cochran (value of C), and Bartlett (Chi-squared) (SoKAL \& RoHLF, 1995). The assumptions were considered broken when the significance level of the tests were below the 0.05 level (SoKAL \& RoHLF, 1995). The normality assumption was broken for two ANOVAs: i) using as response variable the number of individuals and subdividing the demographic groups into five demographic groups $(\mathrm{d}=0.137 ; P<0.01)$; ii) using as response variable the $C L$ and dividing the demographic groups only into male and female $(d=0.035$; $P<0.01)$. The homoscedasticity assumption was broken for three ANOVAs: i) using as response variable the number of individuals and subdividing the demographic groups into five demographic groups ( $\mathrm{F}$ max. $=740.334 ; \mathrm{C}=0.238 ; \chi^{2}$ $=177.571 ; P=0)$; ii) using as response variable the $\mathrm{CL}$ and dividing the demographic groups only into males and females (F max. $\left.=4.014 ; \mathrm{C}=0.323 ; \chi^{2}=850.477 ; P=0\right)$; and iii) using as response variable the $\mathrm{CL}$ and subdividing the demographic groups into five demographic groups $(\mathrm{F}$ max. $=5.976 ; \mathrm{C}=$ $\left.0.157 ; \chi^{2}=436.356 ; P=0\right)$. Therefore, we standardized both response variables (i.e. number of individuals and carapace length) for all ANOVAs. Following SoKAL \& RoHLF (1995) and GOTTELLI \& ELLISON (2011) recommendations we used as standardization algebra the sum of 0.5 value in each measure and then take the square root of this sum. This mathematical procedure is indicated when the response variable is counting data (e.g. the number of individuals), and when the residuals tend to have their distribution to the right (as observed in the ANOVA's residuals, using carapace length as response variable, in the normality test) (SOKAL \& ROHLF, 1995).

\section{RESULTS}

In total, we collected 6,428 individuals of Macrobrachium jelskii, of which 3,149 were males and 3,279 were females. Among the males captured, 114 were considered juveniles and 3,035 adults. Among the females captured, there were 1,672 juveniles and 1,607 adults, from which 220 were ovigerous. Considering the microhabitats, $2,177(34 \%), 2,437(38 \%)$, and 1,814 (28\%) individuals were 
captured in M1, M2, and M3, respectively. There were no significant differences between the total number of individuals in each microhabitat $(F=1.529 ; P=0.224)$.

Considering all individuals captured during the sampling period and in the three microhabitats, $51 \%$ of the population was female (without separating juveniles and adults). Therefore, the overall sex ratio was 1.04 female to 1 male $\left(\chi^{2}=2.59 ; P>0.05\right)$. Considering only two demographic categories (males and females; Fig. 2) the number of females was significantly higher than males in M1 $(\mathrm{F}=13.342 ; P<0.001)$, and there was no difference between the number of males and females in $\mathrm{M} 2$ and $\mathrm{M} 3(F$ $=2.061 ; P=0.135)$. When the data were separated into five demographic categories (Fig. 3) adult males were the most abundant demographic group in M2 and M3 (F = 5.055; $P$ $<0.001$ ), and there was no predominance of a demographic group in M1. Non-ovigerous adult females preferred M1 (F = 93.391; $P=0$ ), while ovigerous adult females and juveniles of both sexes showed no microhabitat preference $(\mathrm{F}=2.4 ; P$ $=0.093)$. However, in the case of ovigerous adult females, it
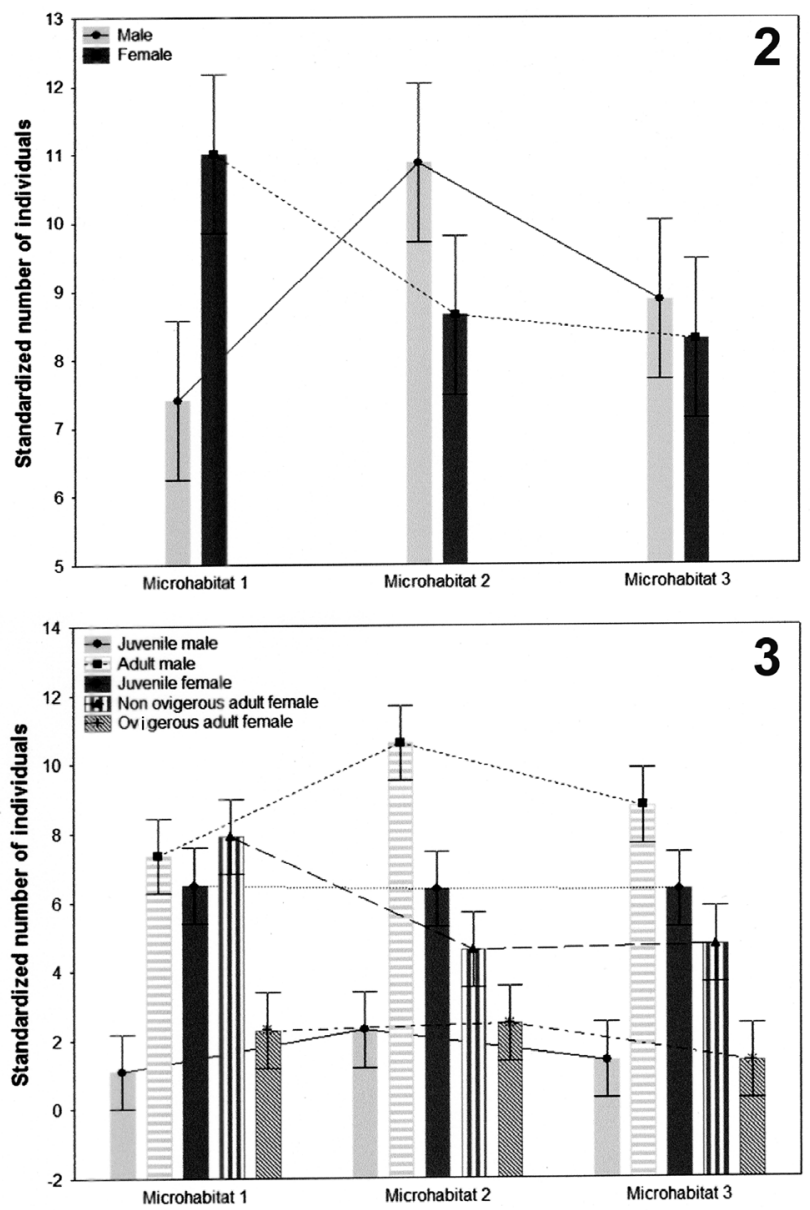

Figs 2, 3. Standardized mean abundance of Macrobrachium jelskii (Miers, 1877) in the three microhabitats studied - Eleocharis sp. (Microhabitat 1), Cabomba sp. (Microhabitat 2), and Nymphaea sp. (Microhabitat 3): Fig. 2, females (squares) and males (circles); Fig. 3, juvenile males (circles), adult males (squares), juvenile females (lozenges), non-ovigerous adult females (triangles) and ovigerous adult females (crosses). Bars represent confidence intervals at 0.95 level.
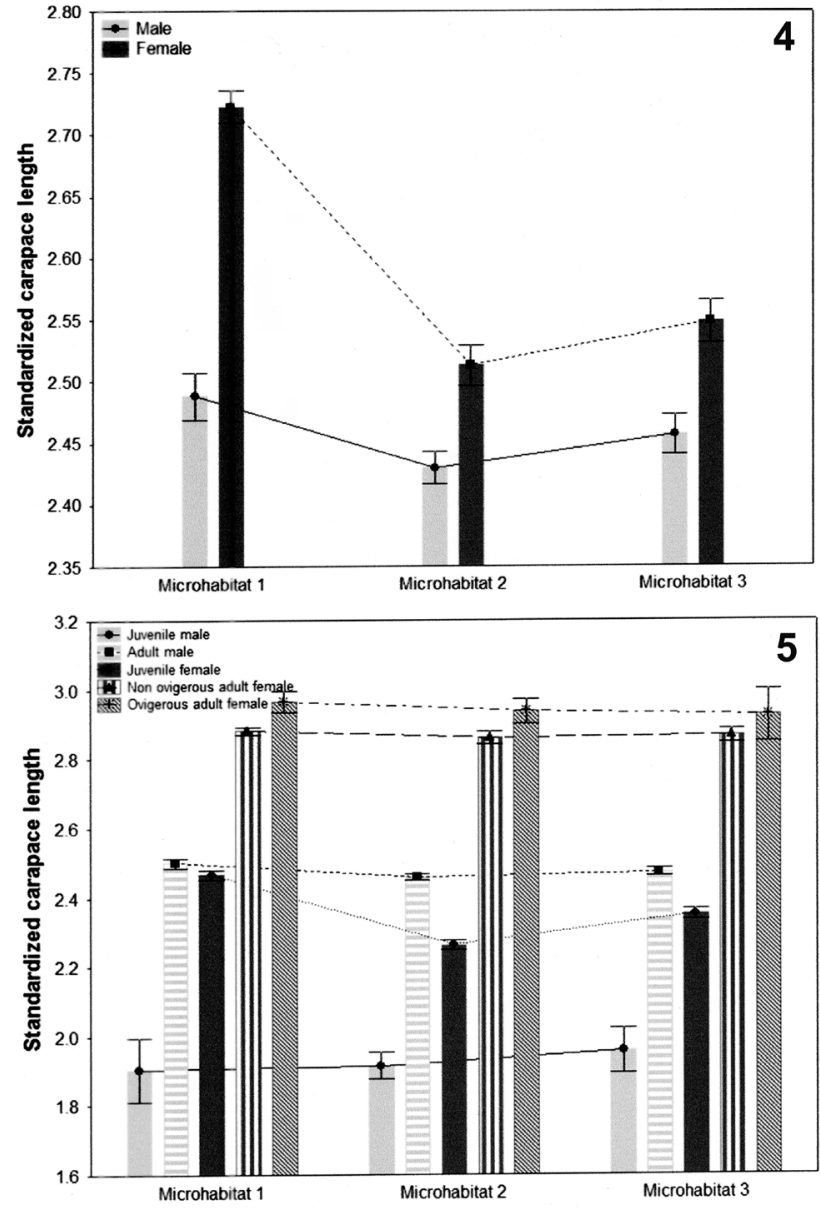

Figs 4, 5. Standardized mean carapace length of Macrobrachium jelskii (Miers, 1877) in the three microhabitats studied - Eleocharis sp. (Microhabitat 1), Cabomba sp. (Microhabitat 2), and Nymphaea sp. (Microhabitat 3): Fig. 4, females (squares) and males (circles); Fig. 5, juvenile males (circles), adult males (squares), juvenile females (lozenges), non-ovigerous adult females (triangles) and ovigerous adult females (crosses). Bars represent confidence intervals at 0.95 level.

is worth mentioning that $112(51 \%)$ specimens were collected in M1, $88(40 \%)$ in M2 and only $20(9 \%)$ in M3.

Male CL (juveniles + adults) ranged from 1.88 to 9.20 $\mathrm{mm}($ Mean $=5.55 \pm 0.95 \mathrm{~mm})$, while female CL (juveniles + adults) ranged from 2.04 to 9.82 (Mean $=6.45 \pm 1.61$ $\mathrm{mm}$ ). The mean CL of juvenile females, non-ovigerous adult females and ovigerous adult females was $5.12 \mathrm{~mm}( \pm 1.05)$, $7.83 \mathrm{~mm}( \pm 0.64)$ and $8.21 \mathrm{~mm}( \pm 0.52)$, respectively. The mean CL of juvenile and adult males was $3.22 \mathrm{~mm}( \pm 0.62)$ and $5.63 \mathrm{~mm}( \pm 0.84)$, respectively. Females were larger than males considering the whole population $(F=419.3$; $P=0)$, only adults $(F=2797.1 ; P=0)$, and only juveniles $(F=2797.1 ; P=0)$.

When the CL was analyzed by microhabitat, females were larger than males in M1, M2, and M3 (Fig. 4). The largest individuals of both sexes were found in M1 $(F=$ 53.6; $P=0$; Fig. 4). Although individuals from M2 were the smallest, the difference was not statistically significant in comparison with individuals from M3 (see bars and confidence intervals in Fig. 4). When adult and juvenile 
males and adult (non-ovigerous and ovigerous) and juvenile females were analyzed separately (Fig. 5), adult females were larger in all microhabitats; ovigerous adult females were significantly larger than non-ovigerous adult females in $\mathrm{M} 1$ and $\mathrm{M} 2(\mathrm{~F}=27.2 .1 ; P=0)$, but not in $\mathrm{M} 3$ (see bars and confidence intervals in Fig. 5). The largest and smallest juvenile females were found in M1 and M2, respectively (Fig. 5). Adult males were significantly larger in M1 than in the other microhabitats $(\mathrm{F}=12.1 ; P=0$; Fig. 5$)$ and were larger than juvenile females in all microhabitats. Juvenile males were the smallest individuals in all microhabitats (Fig. 5). The CL of non-ovigerous and ovigerous adult females and juvenile males did not differ between microhabitats (see bars and confidence intervals in Fig. 5). Finally, the results of two-way ANOVA demonstrated significant differences in the $\mathrm{CL}$ of males and females, both in adult and juvenile in all microhabitats $(F=2027.1 ; P=0)$.

\section{DISCUSSION}

Increase of habitat complexity has a positive effect on biomass and structure (richness, diversity, species composition) of periphyton and the amount of particulate organic matter (WARFE \& BARMUTA, 2006; CASARTELli \& Ferragut, 2018). Compared to Nymphaea sp. the submersed structures of Cabomba sp. and Eleocharis sp. retain greater amount of particulate material colonized by periphyton, epiphyton, aquatic invertebrates, and decomposer organisms such as bacteria and fungi (Thomaz \& BinI, 2003; Hogsden et al., 2007; Thomaz \& CunHa, 2010; CAMARgo \& Ferragut, 2014). Those elements are the main food items of M. jelskii diet (Melo, 2003; CirILO et al., 2011). Therefore, although ANOVA demonstrated that there were no statistical differences between the total numbers of individuals in each microhabitat, $M$. jelskii were more abundant in M1 and M2 (totaling $72 \%$ of all sampled individuals). According to Williner \& ColLins (2002), M. jelskii prefers shallower marginal areas, which require less energy to move in the water column, in comparison with deeper and open-water areas. As observed in our study, shallower waters (less than $100 \mathrm{~cm}$ deep) have higher abundance of more complex macrophytes and thus provide more food resources.

Although food availability is certainly important for all demographic categories of M. jelskii, our data allows us to infer that this is particularly important for adult females. Living in food-rich habitats is especially important for females of carideans prawns that present larger size than males, which is the case for M. jelskii. In this case, females need a significant food supply to maintain their growth rate (HOWARD \& LOWE, 1984) and the high energetic demand of ovary maturation after sexual maturity, spawning and incubation of eggs (SASTRY, 1983; PINHEIRO \& TADDEI, 2005; HaRTNOLl, 2006; AraúJo et al., 2012; Lira et al., 2012). These biological features could explain the higher abundance of non-ovigerous adult females in M1. Moreover, although not statistically significant, the higher relative frequency of ovigerous adult females in M1 and M2 (91\% of all ovigerous females sampled) is also an indicative of the importance of these food-rich microhabitats to the reproduction of M. jelskii. Similarly, ovigerous females of Palaemon pandaliformis (Stimpson, 1871) had a strong preference for E. crassipes, probably associated to the density of this vegetation, especially the roots (PASCHOAL et al., 2013).

The shelter availability is directly proportional to the structural complexity and density of macrophytes, where preys are protected from visual predators, especially fishes (Dibble et al., 1996; Thomaz \& Cunha, 2010). Thus, in addition to the food availability, M1 and M2 could also provide a better protection against predators than M3.

However, WARFE \& BARMUTA (2006) conducted an experiment with artificial analogues of three macrophytes (Myriophyllum sp., Triglochin sp. and Eleocharis sp.) and observed that pygmy perch (predator fish) had their greatest impact on invertebrate grazers in the most structurally complex plant analogue, Myriophyllum sp. (macrophyte similar to Cabomba sp.). Those authors concluded that vulnerable invertebrate grazers might have been unable to perceive the risk of predation in Myriophyllum sp. compared to the other plant analogues. A similar situation might have occurred in Doutor Braz Water Reservoir, where M2, although more complex, might offer greater risk of predation. Thus, M1 although less complex than M2 would offer less risk of predation because Eleocharis sp. is a macrophyte that grows in shallower areas. This hypothesis is corroborated by the preference of the adult non-ovigerous females, the larger adult males and the larger juvenile females for M1 (see Figs. 3 and 5). In this context, Bentes et al. (2011) also observed that riparian river areas provided a better shelter to Macrobrachium amazonicum (HELleR, 1862) against predators due to their lower depth and higher vegetation density. Finally, Rocha (2010) demonstrated that Macrobrachium acanthurus (WIEGMANN, 1836) females prefer living in the riparian vegetation.

The higher abundance of adult males (compared to the other demographic categories) found in M2 and M3 might be related to an intraspecific competition with females (mainly adults) for shelter in M1. Our results demonstrated that the size and number of females are significantly higher than males in M1. According to FigLer et al. (1999) and LAMMERS et al. (2009b), the body size is an important factor during the establishment of social hierarchy and shelter conquer in decapods, regardless of the sex. Therefore, based on the distribution pattern of M. jelskii in the Doutor Braz Water Reservoir, we can infer that the large females inhabiting M1 won the competition for space, displacing smaller females and males to other microhabitats. In this context, it is important to note that the largest adult males were found in M1, probably because they were large enough to won the competition for shelter from smaller juvenile females and males, which spread evenly across all microhabitats. Still, the smaller size of those individuals who could not settle in M1 would be advantageous and allow them to inhabit deeper and less dense microhabitats, since they are less conspicuous to predators. The same result was observed for Macrobrachium acanthurus 
and Macrobrachium olfersii (Wiegmann, 1836), in which large males were seen with groups of females in banks of E. crassipes in Salsa river, Ilhéus, Bahia (PASchOAL et al., 2013). Cabomba sp. is denser than Nymphaea sp. and can grow in shallower areas near M1, where there is a higher concentration of larger adult and juvenile females. These factors would make M2 the preferred microhabitat of males (mainly adults) who could not conquer space in M1 due to their small body size, comparing with adult females.

According to Williner \& Collins (2002), Macrobrachium jelskii males are more active than females. This behavioral difference might be related to the type of reproductive strategy of this species, the pure search (RocHA $\&$ BARBOSA, 2017). In this strategy, males are highly mobile and their reproductive success depends on their ability to fertilize the highest number of females (CORREA \& THIEL, 2003; BAUER, 2004). Therefore, the search for females would stimulate the males to move between the different microhabitats in Doutor Braz Water Reservoir. During these high-activity periods, males could become more vulnerable to predation; however, their small body size is advantageous as it confers a higher mobility and low conspicuousness to predators (CORREA \& THIEL, 2003).

The present study demonstrated the importance of Eleocharis sp., Cabomba sp., and Nymphaea sp. in the distribution, abundance, population structure, and reproduction of $M$. jelskii in a lentic environment. These aquatic macrophytes were confirmed to be a very important component of the microhabitats used by the prawns. Eleocharis sp. is the most preferred microhabitat and is particularly important for adult females, while Cabomba sp. is crucial for adult males. Juveniles of both sexes dispersed equally between all microhabitats and there is an indicative that $\mathrm{M} 1$ and $\mathrm{M} 2$ are important to the reproduction of $M$. jelskii. The main ecological factor influencing the population of $M$. jelskii in these microhabitats is probably the intraspecific competition for food and shelter. Our results help to understand the ecological role and the niche used by this freshwater prawn. Future studies on the habitat choice and predation under laboratory conditions should help to understand the behavior of this species.

Acknowledgements. We express our sincere gratitude to Centro de Ciências Agrárias, Ambientais e Biológicas - Universidade Federal do Recôncavo da Bahia for providing all laboratory facilities. To Dra. Lidyanne Yuriko Saleme Aona Pinheiro (CCAAB - UFRB) for helping us on the macrophytes identification. To Thais Arrais Mota and Rosiane de Jesus Barbosa for their help during sampling. Finally, the authors would like to thank the anonymous reviewers for their helpful and constructive comments that greatly contributed to improving the final version of this paper.

\section{REFERENCES}

ANGer, K. 2013. Neotropical Macrobrachium (Caridea: Palaemonidae): on the biology, origin and radiation of freshwater-invading shrimp. Journal of Crustacean Biology 33:151-183.

Araújo, M. S. L. C.; Castiglioni, D. S. \& Coelho, P. A. 2012. Widthweight relationship and condition factor of Ucides cordatus (Crustacea, Decapoda, Ucididae) at a tropical mangroves of Northeast Brazil. Iheringia, Série Zoologia 102:277-284.
BAUER, R. T. 1976. Mating behaviour and spermatophore transfer in the shrimp Heptacarpus pictus (Stimpson) (Decapoda: Caridea: Hippolytidae). Journal of Natural History 10:415-440.

BAUER, R. T. 2004. Remarkable Shrimps: adaptations and natural history of the carideans. Oklahoma, University of Oklahoma Press. 282p.

Bentes, B. S.; Martinelli, J. M.; Souza, L. S.; Cavalcante, D. V.; Almeida, M. C. \& IsAaC, V. J. 2011. Spatial distribution of the Amazon River prawn Macrobrachium amazonicum (Heller, 1862) (Decapoda, Caridea, Palaemonidae) in two perennial creeks of an estuary on the northern coast of Brazil (Guajará Bay, Belém, Pará). Brazilian Journal of Biology 71:925-935.

BERG, A-B. V. \& SANDIFER, P. A. 1984. Mating behavior of the grass shrimp Palaemonetes pugio (Decapoda, Caridea). Journal of Crustacean Biology 4:417-424.

Camargo, V. M. \& Ferragut, C. 2014. Estrutura da comunidade de algas perifiticas em Eleocharis acutangula (Roxb.) Schult (Cyperaceae) em reservatório tropical raso, São Paulo, SP, Brasil. Hoehnea 41:31-40.

Casarteli, M. \& Ferragut, C. 2018. The effects of habitat complexity on periphyton biomass accumulation and taxonomic structure during colonization. Hydrobiologia 807:233-246.

Cirilo, A. T. O.; SANtos, M. C. \& Nunes, M. L. 2011. Caracterização física e nutricional do camarão "saburica" (Macrobrachium jelskii, Miers, 1877) e de produtos derivados. Scientia Plena 7:1-6.

Coок, W. L. \& Streams, F. A. 1984. Fish predation on Notonecta (Hemiptera): relationship between prey risk and habitat utilization. Oecologia 64:177-183.

Correa, C. \& THIEL, M. 2003. Mating system in caridean shrimp (Decapoda: Caridea) and their evolutionary consequences for sexual dimorphism and reproductive biology. Revista Chilena de Historia Natural 76:187-203.

DARNELL, R. M. 1956. Analysis of a population of the tropical freshwater shrimp, Atya scabra (Leach). The American Naturalist 55:131-138.

De Grave, S. \& Ashelby, C. W. 2013. A re-appraisal of the systematic status of selected genera in Palaemoninae (Crustacea: Decapoda: Palaemonidae). Zootaxa 3734:331-344.

De Grave, S. \& Fransen, C. H. J. M. 2011. Carideorum catalogus: the recent species of the dendrobranchiate, stenopodidean, procarididean and caridean shrimps. Zoologische Mededelingen 85:195-589.

Dibble, E. D.; Killgore, K. J. \& Dick, G. O. 1996. Measurement of plant architecture in seven aquatic plants. Journal of Freshwater Ecology 11:311-318.

Dibble, E. D. \& Thomaz, S. M. 2006. A Simple method to estimate spatial complexity in aquatic plants. Brazilian Archives of Biology and Technology 49:421-428.

Dibble, E. D. \& Thomaz, S. M. 2009. Use of fractal dimension to assess habitat complexity and its influence on dominant invertebrates inhabiting tropical and temperate macrophytes. Journal of Freshwater Ecology 24:93-102.

Ferreira, F. C.; SouZa, U. P. \& Petrere Jr, M. 2010. Zonação longitudinal da ictiofauna em ambientes lóticos. Boletim da Sociedade Brasileira de Limnologia 38:1-17.

Figler, M. H.; Cheverton, H. M. \& Blank, G. S. 1999. Shelter competition in juvenile red swamp crayfish Procambarus clarkii: the influences of sex differences, relative size, and prior residence. Aquaculture 178:63-75.

GambA, A. L. 1984. Different egg-associated and larval development characteristics of Macrobrachium jelskii and Macrobrachium amazonicum (Arthropoda: Crustacea) in a Venezuelan continental lagoon. International Journal of Invertebrate Reproduction and Development 7:135-142.

Giuliatti, T. L. \& Carvalho, E. M. 2009. Distribuição das assembléias de macroinvertebrados bentônicos em dois trechos do córrego Laranja Doce, Dourados/MS. Interbio 3:4-14.

Gotelli, N. J. \& Ellison, A. M. 2011. Princípios de estatística em ecologia. Porto Alegre, Artmed. 528p.

Hartnoll, R. G. 2006. Reproductive investment in Brachyura. Hydrobiologia 557:31-40.

Hogsden, K. L.; SAgER, E. P. S. \& Hutchinson, T. C. 2007. The Impacts of the Non-native macrophyte Cabomba caroliniana on littoral biota of Kasshabog Lake, Ontario. Journal of Great Lakes Research 33:497-504. 
Howard, R. K. \& Lowe, K. W. 1984. Predation by birds as a factor influencing the demography of an intertidal shrimp. Journal of Experimental Marine Biology and Ecology 74:34-52.

Jalihal, D. R.; SANKolli, K. N. \& Shenoy, S. 1993. Evolution of larval developmental patterns and the process of freshwaterization in the prawn genus Macrobrachium Bate, 1868 (Decapoda, Palaemonidae). Crustaceana 65:365-376.

Lammers, J. H.; Warburton, K. \& CribB, B. W. 2009a. Anti-predator strategies in relation to diurnal refuge usage and exploration in the Australian freshwater prawn, Macrobrachium australiense. Journal of Crustacean Biology 29:175-182.

Lammers, J. H.; Warburton, K. \& Cribb, B. W. 2009b. Diurnal refuge competition in the freshwater prawn, Macrobrachium australiense. Journal of Crustacean Biology 29:476-483.

Lima, G. V. \& OshiRo, L. M. Y. 2002. Partição ambiental de Potimirim glabra (Kingsley) e Potimirim potimirim (Müller) (Crustacea, Decapoda, Atyidae) no rio Sahy, Mangaratiba, Rio de Janeiro, Brasil. Revista Brasileira de Zoologia 19:175-179.

Lira, J. J. P. R.; Calado, T. C. S. \& AraúJo, M. S. L. C. 2012. Condition factor of Goniopsis cruentata (Crustacea, Brachyura, Grapsidae) from Mundaú/Manguaba estuarine complex, Alagoas, Brazil. Iheringia, Série Zoologia 102:285-291.

Maciel, C. R.; Quadros, M. L. A.; Abrunhosa, F. A.; Peixoto, S. N. B.; SCHNeIder, H. \& SAMPaIO, M. I. C. 2011. Occurrence of the Indo-Pacific freshwater prawn Macrobrachium equidens Dana, 1852 (Decapoda, Palaemonidae) on the coast of Brazilian Amazonia, with notes on its reproductive biology. Anais da Academia Brasileira de Ciências 83:533-544.

MaGALhÃes, C. 2000. Abbreviated development of Macrobrachium jelskii (Miers, 1877) (Crustacea: Decapoda: Palaemonidae) from the Rio Solimões foodplain, Brazil, reared in the laboratory. Nauplius 8:1-14.

Magalhães, C.; Bueno, S. L. S.; Bond-Buckup, G.; Valenti, W. C.; Silva, H. L. M.; Kiyohara, F.; Mossolin, E. C. \& Rocha, S. S. 2005. Exotic species of freshwater decapod crustaceans in the state of Sao Paulo, Brazil: records and possible causes of their introduction. Biodiversity and Conservation 14:1929-1945.

Magalhães, E. R.; Yamamoto, K. C.; Anjos, H. D. B.; Loebens, S. C. \& SoAres, M. G. 2014. Bancos de macrófitas aquáticas em lago de várzea: alimentação de duas espécies de peixes na região de Manaus, Amazonas, Brasil. Acta of Fisheries and Aquatic Resources 3:25-40.

Marques, M. G. S. M.; Ferreira, R. L. \& Barbosa, F. A. R. 1999. A Comunidade de macroinvertebrados aquáticos e características limnológicas das lagoas Carioca e da Barra, Parque Estadual do rio Doce, MG. Revista Brasileira de Biologia 59:203-210.

McAbendroth, L.; Ramsay, P. M.; FogGo, A.; Rundle, S. D. \& Bilton, D. T. 2005. Does macrophyte fractal complexity drive invertebrate diversity, biomass and body size distributions? Oikos 111:279-290.

Melo, G. A. S. 2003. Famílias Atyidae, Palaemonidae e Sergestida. In: Melo, G. A. S. ed. Manual de identificação dos crustáceos decápodos de água doce Brasileiros. São Paulo, Loyola, p. 289-415.

Merrit, R. W. \& Cummins, K. W. 1996. An Introduction to the Aquatic Insects of North America. Dubuque, Kendall/Hunt Publishing Company. 861p.

Montoya, J. V. 2003. Freshwater shrimps of the genus Macrobrachium associated with roots of Eichhornia crassipes (Water Hyacinth) in the Orinoco Delta (Venezuela). Caribbean Journal of Science 39:155-159.

Müller, Y. M. R.; NaZari, E. M.; Ammar, D.; Ferreira, E. C.; Beltrame, I. T. \& PACHECO, C. 1999. Biologia dos Palaemonidae da bacia hidrográfica de Ratones, Florianópolis, SC, Brasil. Revista Brasileira de Zoologia 16:629-636.

PaIVA, M. P. \& BARreto, V. A. 1960. Notas sobre a biologia do camarão "sossego" "Macrobrachium jelskii" (Miers, 1977) Chace and Holthuis, 1948, numa pequena bacia potamográfica do nordeste brasileiro. Revista Brasileira de Biologia 20:121-139.

Paschoal, L. R. P.; Souza, R. M.; Guimarães, F. J. \& Couto, E. C. G. 2013. Phytophilous caridean shrimps (Atyidae and Palaemonidae) in Salsa River (Canasvieiras, Bahia, Brazil). Nauplius 21:123-126.

Pileggi, L. G.; Magalhães, C.; Bond-Buckup, G. \& Mantelatto, F. L. 2013. New records and extension of the known distribution of some freshwater shrimps in Brazil. Revista Mexicana de Biodiversidad 84:563-574.

Pileggi, L. G. \& Mantelatto, F. L. 2012. Taxonomic revision of doubtful Brazilian freshwater shrimp species of genus Macrobrachium (Decapoda, Palaemonidae). Iheringia, Série Zoologia 102:426-437.

PinheIro, M. A. A. \& TADDEI, F. 2005. Relação peso/largura da carapaça e fator de condição em Dilocarcinus pagei Stimpson (Crustacea, Trichodactylidae), em São José do Rio Preto, São Paulo, Brasil. Revista Brasileira de Zoologia 22:825-829.

Rocha, S. S. 2010. Diferença entre dois métodos de coleta utilizados na captura de crustáceos decápodes em um rio da Estação Ecológica Juréia-Itatins, São Paulo. Iheringia, Série Zoologia 100:116-122.

Rocha, S. S. \& BARBOSA, R. J. 2017. Population biology of Macrobrachium jelskii (Miers, 1877) (Decapoda, Palaemonidae) from an artificial pond in Bahia, Brazil. Nauplius 25:e2017023.

SANTOS, A.; HAYD, L. \& ANGER, K. 2013. A new species of Macrobrachium Spence Bate, 1868 (Decapoda, Palaemonidae), M. pantanalense, from the Pantanal, Brazil. Zootaxa 3700:534-546.

SASTRY, A. N. 1983. Ecological aspects of reproduction. In: VERNBERG, F. J. \& Vernberg, W. B. eds. The biology of Crustacea. Environmental adaptations. New York, Academic Press, p.179-270.

SOKAL, R. R. \& ROHLF, F. J. 1995. Biometry: The Principles and Practice of Statistics in Biological Research. New York, W. H. Freeman and Co. 859 p.

Takeda, A. M.; Souza-Franco, G. M.; Melo, S. M. \& Monkolski, A. 2003. Invertebrados associados às macrófitas aquáticas da planície de inundação do alto rio Paraná (Brasil). In: Thomaz, S. M. \& BinI, L. M. eds. Ecologia e manejo de macrófitas aquáticas. Maringá, EDUEM, p.243-260.

TANigutch, H.; NaKano, S. \& ToKeshi, M. 2003. Influences of habitat complexity on the diversity and abundance of epiphytic invertebrates on plants. Freshwater Biology 48:718-728.

TeixeIrA, R. R. \& Couto, E. C. G. 2012. Crustacea Decapoda capturados através de coleta passiva em um trecho do Rio dos Mangues (Porto Seguro - BA). Biotemas 25:149-156.

Thomaz, S. M. \& BinI, L. M. 2003. Ecologia e manejo de macrófitas aquáticas. Maringá, EDUEM. 341p.

Thomaz, S. M. \& CUNHA, E. R. 2010. The role of macrophytes in habitat structuring in aquatic ecosystems: methods of measurement, causes and consequences on animal assemblages' composition and biodiversity. Acta Limnologica Brasiliensia 22:218-236.

Thomazi, R. D.; KiIfer, W. P.; Ferreira JR, P. D. \& SÁ, F. S. 2008. A sucessão ecológica sazonal de macroinvertebrados bentônicos em diferentes tipos de atratores artificiais no rio Bubu, Cariacica, ES. Natureza on line 6:1-8.

Vera-Silva, A. L.; Carvalho, F. L. \& Mantelatto, F. 2016. Distribution and genetic differentiation of Macrobrachium jelskii (Miers, 1877) (Natantia: Palaemonidae) in Brazil reveal evidence of non-natural introduction and cryptic allopatric speciation. Journal of Crustacean Biology 36:1-11.

Vera-Silva, A. L.; Carvalho, F. L. \& Mantelatto, F. 2017. Redescription of the freshwater shrimp Macrobrachium jelskii (Miers, 1877) (Caridea, Palaemonidae). Zootaxa 4269:44-60.

WALKer, I. \& Ferreira, M. J. N. 1985. On the population dynamics and ecology of the shrimp species (Crustacea, Decapoda, Natantia) in the Central Amazonian river Tarumã-Mirim. Oecologia 66:264-270.

WARFE, D. M. \& BARMUTA, L. A. 2004. Habitat structural complexity mediates the foraging success of multiple predator species. Oecologia 141:171-178.

Warfe, D. M. \& Barmuta, L. A. 2006. Habitat structural complexity mediates food web dynamics in a freshwater macrophyte community. Oecologia 150:141-154

Warfe, D. M.; Barmuta, L. A. \& Wotherspoon, S. 2008. Quantifying habitat structure: surface convolution and living space for species in complex environments. Oikos 117:1764-1773.

WiLliner, V. \& ColLins, P. 2002. Variación espacio-temporal de la actividad del camarón dulceacuícola Macrobrachium jelskii (Miers, 1877) (Crustacea, Decapoda, Caridea, Palaemonidae). Ecología Austral 12:3-10.

ZAR, J. H. 1996. Biostatistical Analysis. New Jersey, Prentice Hall. 662p. 